\title{
Comparison of leaf anatomy and essential oils from Drimys brasiliensis Miers in a montane cloud forest in Itamonte, MG, Brazil
}

\author{
Bruna Paula da Cruz ${ }^{1 *}$, Evaristo Mauro de Castro ${ }^{1}$, Maria das Graças Cardoso², Katiúscia Freire de Souza ${ }^{1}$, \\ Samísia Maria Fernandes Machado ${ }^{3}$, Patrícia Vieira Pompeu ${ }^{4}$ and Marco Aurélio Leite Fontes ${ }^{4}$
}

\begin{abstract}
Background: Drimys brasiliensis Miers is native to Brazil, where it is mainly found in montane forests and flooded areas in the South and Southeast regions of the country. The objectives of the present study were to compare the leaf anatomy and the chemical constitution of the essential oils from D. brasiliensis present in two altitude levels (1900 and 2100 m), in a Montane Cloud Forest, in Itamonte, MG, Brazil.

Results: A higher number of sclereids was observed in the mesophyll of the leaves at $1900 \mathrm{~m}$ altitude. At $2100 \mathrm{~m}$, the formation of papillae was observed on the abaxial surface of the leaves, as well as an increase in the stomatal density and index, a reduction in leaf tissue thickness, an increase in the abundance of intercellular spaces in the mesophyll and an increase in stomatal conductance and in carbon accumulation in the leaves. Fifty-nine constituents have been identified in the oils, with the predominance of sesquiterpenes. Two trends could be inferred for the species in relation to its secondary metabolism and the altitude. The biosyntheses of sesquiterpene alcohols at $1900 \mathrm{~m}$, and phenylpropanoids and epi-cyclocolorenone at $2100 \mathrm{~m}$, were favored.

Conclusions: $D$. brasiliensis presented a high phenotypic plasticity at the altitude levels studied. In relation to its leaf anatomy, the species showed adaptive characteristics, which can maximize the absorption of $\mathrm{CO}_{2}$ at $2100 \mathrm{~m}$ altitude, where a reduction in the partial pressure of this atmospheric gas occurs. Its essential oils presented promising compounds for the future evaluation of biological potentialities.
\end{abstract}

Keywords: Drimys brasiliensis; Altitude; Cloud Forest; Essential oils; Leaf anatomy

\section{Background}

The Mantiqueira Mountains are a part of the Atlantic Forest domain in Brazil, in which altitudinal forests are located, and can be classified as Cloud Forests, since they are practically covered by fog during most of the year. These forests represent biodiverse and endemic unique ecosystems, which are generally fragmented and threatened, and present a vegetation which is not well studied yet (Aldrich et al. 1997; Bertoncello et al. 2011). Studies conducted by Bertoncello et al. (2011) showed that Drimys brasiliensis Miers is considered one of the indicator species of cloud forests in the South and Southeast regions

\footnotetext{
*Correspondence: brunacruz@dqi.ufla.br

1 Departamento de Biologia, Universidade Federal de Lavras, Campus

Universitário, PO Box 3037, CEP 37200-000, Lavras, MG, Brazil

Full list of author information is available at the end of the article
}

of Brazil. In addition, studies by Meireles et al. (2008) suggested that the species presents its best development in montane environments.

D. brasiliensis is an aromatic species, which belongs to the Winteraceae family. It is native to Brazil, where it is popularly known as cataia or casca-d'anta and it is mainly found in montane forests and flooded areas in the South and Southeast regions of the country (Lorenzi and Matos 2008; Souza and Lorenzi 2008). The species has a peculiar anatomic structure among the angiosperms of the Brazilian flora, as it does not present vessel elements on the xylem, and the stomatal pores are clogged with plugs, comprised of cutin and wax (Feild et al. 2000; Souza and Lorenzi 2008; Marquínez et al. 2009).

The essential oils from $D$. brasiliensis are rich in sesquiterpenes, which call the attention because of the 
variety of biological activities that they present, such as anti-bacterial, anti-inflammatory, anti-allergic and antifungal (Limberger et al. 2007; Ribeiro et al. 2008; Lago et al. 2010). The production of essential oils in plants and other secondary metabolites is constantly influenced by environmental factors (Gobbo-Neto and Lopes 2007), which also cause modifications in the leaf anatomic structures of the plants (Kofidis et al. 2007; Zarinkamar et al. 2011). In altitudinal forests, atmospheric pressure, temperature, radiation, humidity and wind speed are some of the factors that suffer alterations with the increase in the altitudinal gradient and directly influence vegetation (Körner 2007).

Evaluations of leaf anatomy, such as analyses of stomatal density and index, are essential for the comprehension of the gas exchange between the plants and the atmosphere. They become relevant mainly if the new scenarios of climatic changes for the future are considered (Zhou et al. 2012), with the increase in the atmospheric $\mathrm{CO}_{2}$ concentration, among other impacts (Joly 2007). The objectives of the present study were to compare the leaf anatomy and the chemical constitution of the essential oils from D. brasiliensis present in two altitude levels (1900 and $2100 \mathrm{~m}$ ), in a Montane Cloud Forest in the Mantiqueira Mountains, in Itamonte, MG, Brazil.

\section{Methods}

\section{Plant material}

Leaves and branches from Drimys brasiliensis Miers were collected in a Montane Cloud Forest, above the $1500 \mathrm{~m}$ altitude level (Veloso et al. 1991), inside the Mantiqueira Mountains, Atlantic Forest domain, in the city of Itamonte, South of the state of Minas Gerais, Brazil. The collection was carried out in January 2013 at two altitude levels (1900 and $2100 \mathrm{~m})$. The leaves and branches were collected in adult plants, in the east face of the crown. Voucher species were deposited at the ESAL Herbarium of Universidade Federal de Lavras under numbers 27307 and 27216.

The study area is situated at a Private Natural Heritage Reserve, called RPPN Alto-Montana, and integrates the Mantiqueira Mountains Environmental Preservation Area, characterized by a Federal Conservation Unit for Sustainable Use. The approximate geographic coordinates of the area are $22^{\circ} 21^{\prime} 55^{\prime \prime} \mathrm{S}$ e $44^{\circ} 48^{\prime} 32^{\prime \prime} \mathrm{W}$. The area is situated $15 \mathrm{~km}$ away from the entrance of the National Park of Itatiaia [Parque Nacional do Itatiaia].

The climate in the city of Itamonte according to the Köppen classification is Cwb - mesothermal climate with dry winter, mild summer and rainy season in the summer. The average temperature of the warmest month is less than $17.3^{\circ} \mathrm{C}$ and the lowest is more than $12.7^{\circ} \mathrm{C}$ (Sá Júnior et al. 2012). The historical average annual rainfall is $1749 \mathrm{~mm}$. The predominant soil is cambisol (Pane and Pereira 2005).

\section{Characterization of leaf anatomy}

The anatomic characterization was carried out in Laboratório de Anatomia Vegetal of Departamento de Biologia from Universidade Federal de Lavras, Brazil. Fully expanded leaves were selected, free of pathogens, from 4 individuals of $D$. brasiliensis/altitude level (1900 and $2100 \mathrm{~m}$ ). Paradermal and cross sections were carried out on 3 leaves/ individual and 5 fields/leaf were analyzed.

The paradermal sections were carried out on both leaf surfaces (adaxial and abaxial), manually, with the help of a steel blade. The sections were clarified in a $50 \%$ sodium hypochlorite solution for about 1 minute and then they were washed in distilled water two times for 10 minutes, and flushed with $1 \%$ safranin. The sections were mounted on slides and coverslips with 50\% glycerin (Kraus and Arduin 1997) and photographed in an Olympus CX 31 optical microscope, coupled to a digital camera. The stomatal analysis was carried out on the abaxial surface of the leaves, where the stomata were present, through the image analysis software UTHSCSA-Imagetool ${ }^{\circ}$, version 3.0. Density (number of stomata per $\mathrm{mm}^{2}$ ), functionality (stomatal polar diameter/stomatal equatorial diameter) and stomatal index [(number of stomata/number of stomata + number of epidermal cells) 100] were measured according to Pereira et al. (2011).

The cross sections were carried out from approximately $2 \mathrm{~cm}^{2}$ fragments, taken from the region that contains the central vein. In order to obtain permanent slides, leaf fragments were dehydrated in increasing series of ethanol and preserved in 70\% ethylic alcohol. The inclusion was made in hydroxyethyl methacrylate Leica ${ }^{\circ}$, according to the manufacturer's modified protocol. The samples were sectioned in a semi-automatic microtome, the sections were submitted to staining with toluidine blue and the slides were mounted in Permount ${ }^{\circ}$ (Feder and O'Brien 1968). The sections were photographed in a Zeiss optical microscope, coupled to a digital camera (AxioCam ERc5s) and analyzed through the UTHSCSAImagetool $^{\circ}$ software, version 3.0; the characteristics of the leaf tissues were measured.

\section{Histochemical tests}

Histochemical tests were carried out in Laboratório de Anatomia Vegetal of Departamento de Biologia from Universidade Federal de Lavras, Brazil, according to the methodology proposed by Figueiredo et al. (2007). The tests were applied on 3 leaves/individual of $D$. brasiliensis, being 4 individuals/altitude level (1900 and $2100 \mathrm{~m}$ ). The cross sections were carried out from approximately $2 \mathrm{~cm}^{2}$ fragments, taken from the region that contains the central vein with the help of an LPC bench microtome.

For the detection of total lipids, the reagent Sudan IV was used; for the detection of the essential oils, the reagent NADI was used, and for the verification of the 
phenolic compounds, ferric chloride was used. The sections were mounted on slides and coverslips with 50\% glycerin, and photographed in an Olympus CX 31 optical microscope, coupled to a digital camera.

\section{Scanning electron microscopy}

In order to observe the surfaces of $D$. brasiliensis leaves, samples obtained at 1900 and $2100 \mathrm{~m}$ altitude were fixed in a Karnovsky solution until the analysis. In Laboratório de Microscopia Eletrônica e Análise Ultraestrutural of Departamento de Fitopatologia from Universidade Federal de Lavras, Brazil, the samples were washed in a $0.05 \mathrm{M}$ cacodylate buffer (3 times - 10 minutes each) and postfixed in $1 \%$ osmium tetroxide, during 4 hours, at room temperature. Later, they were dehydrated in increasing series of acetone $(25 \%, 50 \%, 75 \%, 90 \%$ and $100 \%, 3$ times 10 minutes each), submitted to the critical point of $\mathrm{CO}_{2}$ desiccation, in a BAL-TEC, CPD-030 equipment, and fixed on a metal support with silver adhesive and recovered with metal gold $(10 \mathrm{~nm})$ in a BAL-TEC, SCD-050 device. The prepared leaf material was observed and electro-micrographed in a LEO EVO 40 XVP scanning electron microscope.

\section{Leaf gas exchange measurements}

Leaf gas exchange characteristics from 4 individuals of $D$. brasiliensis/altitude level (1900 and $2100 \mathrm{~m})$ were evaluated, with an infrared gas analyzer - IRGA (LI-6400XT, LI-COR, USA), in 4 fully expanded leaves/individual, starting at 10 o'clock. Stomatal conductance $\left(g_{s}\right)$, leaf transpiration rate $(\mathrm{E})$ and internal carbon rate $(\mathrm{Ci})$ were evaluated in the leaves.

\section{Extraction of the essential oils}

The extractions of the essential oils were carried out in Laboratório de Química Orgânica - Óleos Essenciais of Departamento de Química from Universidade Federal de Lavras, Brazil. The hydrodistillation method was used, with a Clevenger-type apparatus coupled to a glass flask with round bottom and capacity of $1000 \mathrm{~mL}$, according to the methodology proposed by Brazilian Pharmacopeia (Brasil 2010).

The extractions of the oils were carried out from fresh leaves, fresh branches and dry leaves from 4 individuals of D. brasiliensis/altitude level (1900 and $2100 \mathrm{~m}$ ), considering that the weight of each plant material was previously standardized. The whole plant material was cleaned with tissue paper. The leaves were cut in small and uniform pieces and the branches were cut in pieces of approximately $3 \mathrm{~cm}$. Drying was carried out in a forced air circulation oven (Fanem Model 320 - SE), at temperatures between 30 and $34^{\circ} \mathrm{C}$.

The leaves and the branches were placed in the glass flask and covered with water. The flasks were heated $\left(100 \pm 5^{\circ} \mathrm{C}\right)$ with the help of heating blankets. The extraction process was carried out in a period of 2 hours; the solution was kept boiling. The oil was then separated from the hydrolate by centrifugation, using a bench centrifuge with an horizontal cross arm (Fanem Baby I Model $206 \mathrm{BL}$ ) at $965,36 \times \mathrm{G}$ for 5 minutes. The oil was withdrawn with the help of a Pasteur pipette, placed in a dark glass flask wrapped with aluminum foil and stored under refrigeration.

In parallel with the extractions, a humidity test was carried out, according to Pimentel et al. (2008), for a further calculation of the extraction yield. Five grams of each plant material (fresh leaves and fresh branches) were used, submerged in $50 \mathrm{~mL}$ cyclohexane in a round bottom glass flask with capacity $250 \mathrm{~mL}$, which was coupled to a condenser with a Dean Stark apparatus (distillation trap). The flask was heated $\left(100 \pm 5^{\circ} \mathrm{C}\right)$ with the help of a heating blanket. After 2 hours, the water volume present in the plant material was quantified. The humidity was calculated considering the water content in $100 \mathrm{~g}$ sample.

Each extraction yield was calculated and expressed in oil weight per plant material weight with Humidity Free Base (\% p/p HFB) (Guimarães et al. 2008).

\section{Quantitative and qualitative analyses of the essential oils}

The quantitative and qualitative analyses of the essential oils were carried out in Departamento de Química from Universidade Federal de Sergipe, Brazil. Quantitative analyses were carried out in a Shimadzu GC-17A gas chromatograph equipped with a flame ionization detector (GC-FID), under the following operational conditions: ZB-5MS fused silica capillary column (5\% dimethylpolysiloxane), with $30 \mathrm{~m} \times 0.25 \mathrm{~mm}$ i.d. $\times$ $0.25 \mu \mathrm{m}$ film, using helium as a carrier gas, with $1.2 \mathrm{~mL} \mathrm{~min}^{-1}$ flow rate. The temperature was kept at $50^{\circ} \mathrm{C}$ for $2 \mathrm{~min}$, followed by an increase of $4^{\circ} \mathrm{C} \mathrm{min}^{-1}$, until achieving $200^{\circ} \mathrm{C}$. Then, it was increased by $15^{\circ} \mathrm{C} \mathrm{m^{-1 }}$, until achieving $300^{\circ} \mathrm{C}$, and this temperature was kept for $15 \mathrm{~min}$. The injector temperature was $250^{\circ} \mathrm{C}$ and the detector temperature (or interface), was $280^{\circ} \mathrm{C}$. The injected sample volume was $0.5 \mu \mathrm{L}$ in ethyl acetate.

Qualitative analyses were carried out in a Shimadzu QP 5050A gas chromatograph coupled to a mass spectrometer (GC-MS), equipped with a J\&W Scientific fused silica capillary column (5\%-phenyl-95\%-dimethylpolysiloxane), with $30 \mathrm{~m} \times 0.25 \mathrm{~mm}$ i.d. $\times 0.25 \mu \mathrm{m}$ film, using helium as a carrier gas, with $1.2 \mathrm{~mL} \mathrm{~min}^{-1}$ flow rate. The chromatographic conditions of the analyses were the same as the ones used for GC-FID. The MS operational conditions were: ionic capture detector operating by electronic impact and impact energy at $70 \mathrm{eV}$; scanning speed 1000; scanning interval 0.50 fragments 
per second and fragments detected in the range of 40 to $500 \mathrm{Da}$

The identification of the constituents was carried out based on the comparison of its retention indexes with the ones in the literature (Adams 2007). For the calculation of the retention index, the Dool and Kratz equation (1963) was used in relation to homologous series of nalkanes $\left(\mathrm{nC}_{9}-\mathrm{nC}_{18}\right)$. Two equipment libraries have also been used (NIST107 and NIST21), which allow the comparison of the obtained spectrum data with those existing in the libraries.

\section{Microclimatic data}

The microclimatic data were provided by collaborators from Departamento de Ciências Florestais from Universidade Federal de Lavras, Brazil, and refer to the period of one year follow-up by a meteorological station of the brand WatchDog model 2900ET, installed in each altitude level (1900 and $2100 \mathrm{~m}$ ).

\section{Statistical analyses}

The data related to $D$. brasiliensis leaf anatomy and leaf gas exchanges were submitted to a variance analysis, and the means were compared by the Scott-Knott test at 95\% confidence, using the statistical program SISVAR, version 4.6 (Ferreira 2003). For the leaf anatomy analysis, the results obtained from 5 field/leaf were considered, being 3 leaves/individual of $D$. brasiliensis and 4 individuals/altitude level (1900 and $2100 \mathrm{~m}$ ) and, for the leaf gas exchange analysis, the data obtained from 4 leaves/individual were considered, being 4 individuals/ altitude level.

Due to the big quantity of chemical compounds present in the essential oils from $D$. brasiliensis, the PCA technique (Principal Component Analysis) was chosen to check the similarity between the essential oils from the fresh leaves (FF), dry leaves (FS) and fresh branches (G) in two altitude levels, regarding the proportions of their chemical constituents. The analysis was carried out using the program CHEMOFACE (Nunes et al. 2012). For this analysis, the means of the proportions of the chemical constituents of the oils from 4 individuals of D. brasiliensis/altitude level (1900 and $2100 \mathrm{~m}$ ) were calculated.

\section{Results and discussion}

\section{Morpho-anatomical properties of $D$. brasiliensis leaves}

In the cross section, $D$. brasiliensis leaves presented a uniseriate epidermis, externally coated by a cuticle, whose thickness ranged according to the altitude, and a dorsiventral mesophyll, with a palisade parenchyma in which there were three cell layers, and a spongy parenchyma with six to eight layers (Figure 1a, b). In both altitude levels, the stomata found were of the paracitic type and were present only on the abaxial surface of $D$. brasiliensis leaves; these were classified as hypostomatal, which is in accordance with the descriptions for the representatives of the Winteraceae family (Feild et al. 1998; Feild et al. 2000).

In the mesophyll, sclerenchyma cells of the sclereid type were found with round and elliptical shape (Figure 1a, e). Metcalfe and Chalk (1957) report the presence of such sclereids in the representatives of the Winteraceae family. Sclereids were present in a higher amount in D. brasiliensis leaves collected at $1900 \mathrm{~m}$ altitude (Table 1), while intercellular spaces occurred in higher abundance in the mesophyll of the leaves at $2100 \mathrm{~m}$ (Figure 1b; Table 1). The central vein of $D$. brasiliensis leaves collected at $1900 \mathrm{~m}$ altitude (Figure 1c), presented many sclereids like the ones in the mesophyll, in addition to a higher number of secretory cavities (Table 1).

The histochemical tests carried out in this study helped identify cavities and cells or secretory idioblasts with oil content in D. brasiliensis leaves. These structures were found in both altitude levels. The presence of secretory cells has already been reported for the species of the Winteraceae family (Metcalfe and Chalk 1957; West 1969; Esau 1974; Read and Menary 2000). The histochemical tests also identified phenolic compounds in the mesophyll of $D$. brasiliensis leaves.

The abaxial surface of $D$. brasiliensis leaves collected at $2100 \mathrm{~m}$ altitude presented abundant papillae with variable length (Figure 1b, f; Figure 2). These structures were not found in the leaves collected at $1900 \mathrm{~m}$. Smith (1943), Metcalfe and Chalk (1957), Ehrendorfer et al. (1979), Feild et al. (1998), Feild et al. (2000) and Eller et al. (2013) reported the presence of papillae on the abaxial surface of Drimys sp. leaves; however, the authors did not present any differences in the occurrence of these epidermal structures in relation to biotic and abiotic factors. Vieira and Gomes (1995) attributed the function to converge light stimuli for the mesophyll to the papillae of the abaxial epidermis from Psychotria leiocarpa Cham. and Schltdl., P. stenocalyx Müll. Arg. and P. tenuinervis Müll. Arg. (Rubiaceae) leaves, for the performance of photosynthesis, since the studied leaves developed under reduced luminosity.

Recent studies conducted by Eller et al. (2013) proved that $D$. brasiliensis is able to absorb water from the fog through the cuticle of the leaves and, according to these authors, this is an essential process for the wide distribution of the species in cloud forests. The authors suggested that the water absorption in $D$. brasiliensis leaves occurs mainly on the adaxial surface, and the abaxial surface is responsible for gas exchange during and after the presence of the fogs, because of its hydrophobic characteristics and because it contains most of the stomata.

Feild et al. (1998), studying the species Drimys winteri var. chilensis (DC) A. Gray, evidenced that the plugs of 


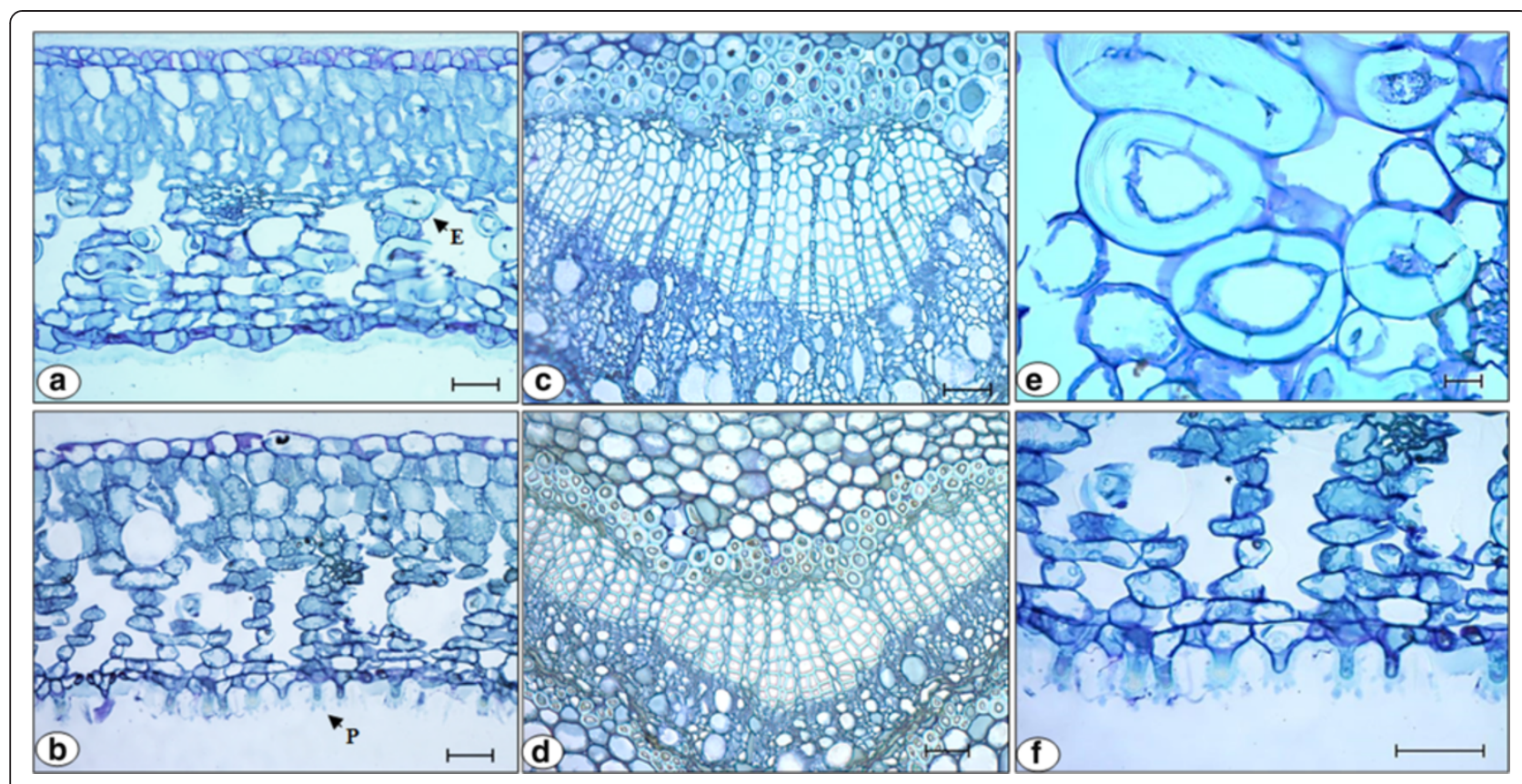

Figure 1 Cross sections of Drimys brasiliensis Miers leaves collected at $1900 \mathrm{~m} \mathrm{(a,} \mathrm{c,} \mathrm{e)} \mathrm{and} 2100 \mathrm{~m} \mathrm{(b,} \mathrm{d,} \mathrm{f)} \mathrm{altitude} \mathrm{in} \mathrm{a} \mathrm{Montane} \mathrm{Cloud}$ Forest in Itamonte, MG, Brazil, evidencing the central vein of the leaves $(c, d)$, the sclereids (e) and the papillose epidermis ( $f$ ). $E=A$ sclereid, $\mathrm{P}=$ A papilla. Bars: $50 \mu \mathrm{m}(\mathbf{a}, \mathbf{b}, \mathbf{c}, \mathbf{d}, \mathbf{f}), 20 \mu \mathrm{m}(\mathbf{e})$.

the stomata (constituted of cuticle material) present on the abaxial surface of Drimys leaves, are responsible for the protection of the leaves against excessive soaking caused by the recurring fog in cloud forests. The authors discuss that the plugs, together with the papillae and epicuticular waxes, due to their high hydrophobicity, comprise a structure which is able to prevent the constant formation of water films on the leaves, that would make gas exchange difficult. The authors also clarify that the diffusion of $\mathrm{CO}_{2}$ in water is much slower than in the air (about 10000 times), so a water film on the leaves

Table 1 Anatomical characteristics of Drimys brasiliensis Miers leaf tissues present at 1900 and $2100 \mathrm{~m}$ altitude in a Montane Cloud Forest in Itamonte, MG, Brazil

\begin{tabular}{ccc}
\hline & $\mathbf{1 9 0 0}$ & $\mathbf{2 1 0 0}$ \\
\hline $\mathrm{LL}(\mu \mathrm{m})$ & $433.55 \pm 53.05 \mathrm{a}$ & $330.94 \pm 32.34 \mathrm{~b}$ \\
$\mathrm{CT}(\mu \mathrm{m})$ & $12.43 \pm 3.34 \mathrm{a}$ & $7.98 \pm 1.04 \mathrm{~b}$ \\
$\mathrm{PP}(\mu \mathrm{m})$ & $130.51 \pm 21.24 \mathrm{a}$ & $102.64 \pm 9.23 \mathrm{~b}$ \\
$\mathrm{SP}(\mu \mathrm{m})$ & $200.02 \pm 21.09 \mathrm{a}$ & $146.44 \pm 20.96 \mathrm{~b}$ \\
$\mathrm{SCL}$ & $10.60 \pm 0.96 \mathrm{a}$ & $3.35 \pm 0.44 \mathrm{~b}$ \\
$\mathrm{AIS}$ & $0.11 \pm 0.01 \mathrm{a}$ & $0.22 \pm 0.01 \mathrm{~b}$ \\
$\mathrm{SC}$ & $7.88 \pm 0.47 \mathrm{a}$ & $4.20 \pm 0.69 \mathrm{~b}$ \\
\hline
\end{tabular}

LL, Thickness of the leaf lamina; $\mathrm{CT}$, Thickness of the cuticle of the adaxial surface; PP, Thickness of the palisade parenchyma; SP, Thickness of the spongy parenchyma; SCL, Number of sclereids in the mesophyll; AIS, Abundance of intercellular spaces in the mesophyll (Area/Area); SC, Number of secretory cavities near the central vein. All values are expressed as the mean \pm standard deviation. Means followed by the same letter in rows $(a, b)$ do not differ by the Scott-Knott test $(P<0.05)$. would reduce gas exchange, because it would create a barrier for the entrance of $\mathrm{CO}_{2}$ in the leaves. Brewer and Smith (1997), evaluating 50 montane species at $2400 \mathrm{~m}$ altitude in the USA, also discussed this issue, attributing a fundamental role regarding the avoidance of water film formation on the leaves to the leaf trichomes.

Based on the presented evidences, it can be inferred that the occurrence of papillae in D. brasiliensis individuals at $2100 \mathrm{~m}$ altitude is possibly related to the higher humidity at this altitude level (Table 2) and to the reduction of the partial pressure of $\mathrm{CO}_{2}$ with the increase in altitude (Körner 2007). The papillae present on the abaxial surface of the leaves would favor the absorption of $\mathrm{CO}_{2}$ through the same process described for $D$. winteri by Feild et al. (1998), i.e. comprising a hydrophobic matrix, which would avoid the formation of a water film on the leaves. Complementing these data, the leaf transpiration of $D$. brasiliensis was higher at $2100 \mathrm{~m}$ altitude (Table 3), preventing the accumulation of water on the leaves and compensating the higher humidity at this altitude level (Table 2). Our results confirm the proposal of Feild et al. (1998) and aggregate knowledge, and also present the phenotypic plasticity of $D$. brasiliensis in altitudinal forests, being able to alter/favor the formation of papillae as a compensatory mechanism for the reduction of the partial pressure of $\mathrm{CO}_{2}$ at higher altitudes.

Other results, which complement this hypothesis, are presented in Tables 3 and 4. Through the analysis of these results, it is possible to observe that the average 

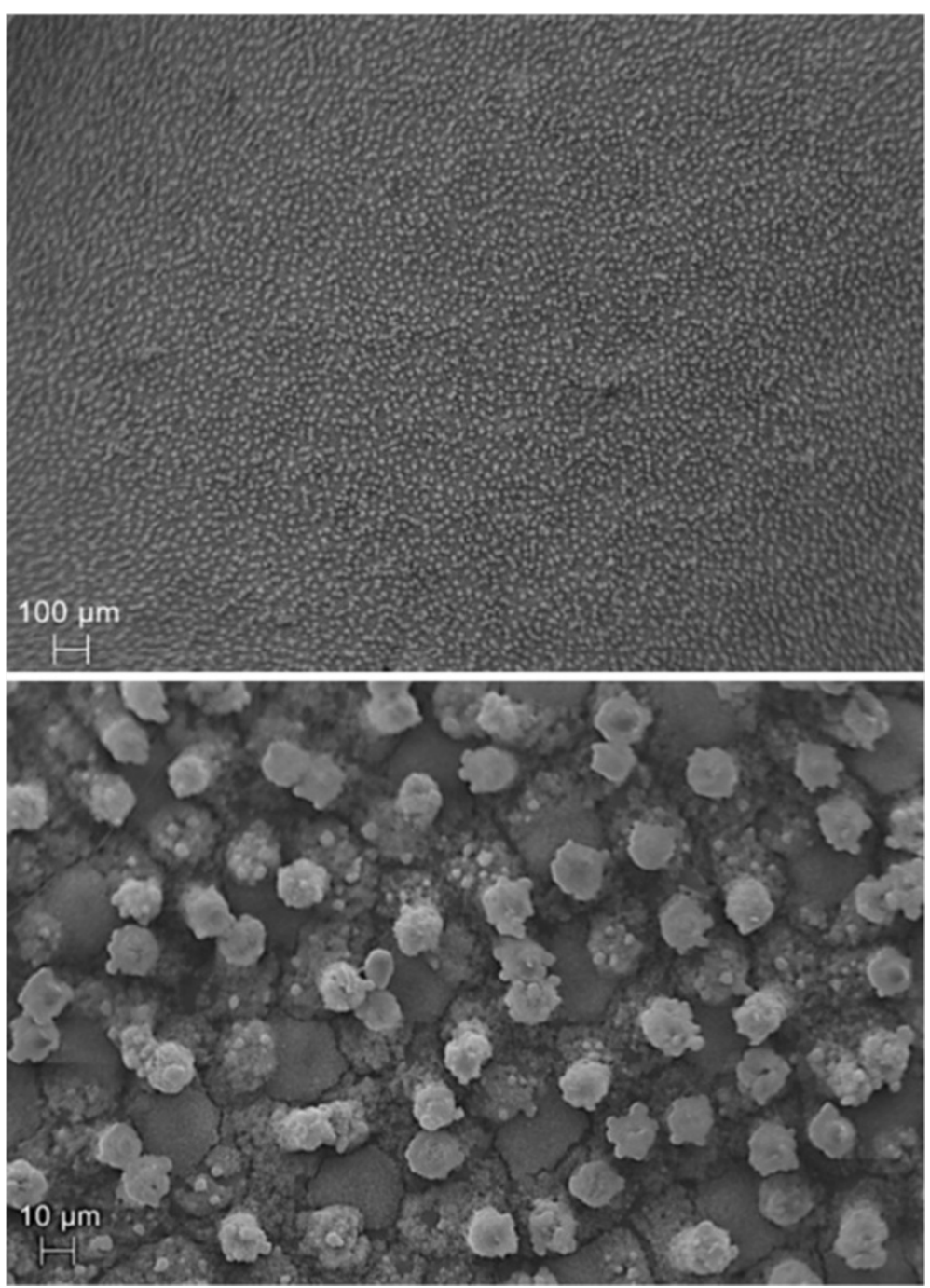

Figure 2 Scanning electron microscopy of the abaxial surface of Drimys brasiliensis Miers leaves collected at $2100 \mathrm{~m}$ altitude in a Montane Cloud Forest in Itamonte, MG, Brazil, evidencing the papillose epidermis.

stomatal density and index of $D$. brasiliensis individuals at $2100 \mathrm{~m}$ altitude were statistically higher than the ones at $1900 \mathrm{~m}$ (Table 4). The strategy of the species would be to invest in a higher stomatal production to compensate the lower availability of atmospheric $\mathrm{CO}_{2}$ at $2100 \mathrm{~m}$ altitude. Furthermore, the stomatal conductance at $2100 \mathrm{~m}$ altitude presented values that were superior to those at $1900 \mathrm{~m}$, facilitating the accumulation of carbon in the leaves (Table 3). This accumulation was also facilitated by the greater abundance of intercellular spaces in the mesophyll of the leaves at $2100 \mathrm{~m}$ (Table 1). Thus, it can be proposed that the hydrophobic surface formed by the papillae (Figure 1b, f; Figure 2) could act together with the increase in the number of stomata (Table 4) and the higher stomatal conductance (Table 3), establishing an adaptive strategy, which would favor gas exchange in $D$. brasiliensis leaves, compensating the reduction in the partial pressure of $\mathrm{CO}_{2}$ at $2100 \mathrm{~m}$ altitude.

The differentiation of stomata is genetically determined and suffers the influence of environmental factors, such as the concentration of atmospheric $\mathrm{CO}_{2}$, temperature, humidity and luminosity (Li et al. 2006; Zhao et al. 2008; Zhou et al. 2012). Different authors report the positive correlation between the increase in the number of stomata and the elevation in altitude for several species, such as Eucalyptus pauciflora Sieb. ex Spreng. (Körner and Cochrane 1985), Vaccinium myrtillus L. (Woodward 1986), Clinopodium vulgare L. (Kofidis et al. 2007) and Nepeta nuda L. (Kofidis and Bosabalidis 2008).

According to Kouwenberg et al. (2007), the reduction in the partial pressure of $\mathrm{CO}_{2}$ plays an essential role in the increase in stomatal density for many species with the elevation in altitude. The authors discuss that, 
Table 2 Average microclimate parameters in two altitude levels (1900 and $2100 \mathrm{~m}$ ) in a Montane Cloud Forest in Itamonte, MG, Brazil

\begin{tabular}{lrr}
\hline & $\mathbf{1 9 0 0}$ & $\mathbf{2 1 0 0}$ \\
\hline Radiation $\left(\right.$ watt $\left./ \mathrm{m}^{2}\right)$ & 11.2 & 24.6 \\
Sun hours $(\mathrm{h})$ & 8.0 & 8.6 \\
Air relative humidity $(\%)$ & 81.6 & 83.5 \\
Maximum humidity $(\%)$ & 91.3 & 94.0 \\
Minimum humidity $(\%)$ & 68.0 & 67.0 \\
Temperature $\left({ }^{\circ} \mathrm{C}\right)$ & 13.1 & 11.8 \\
Maximum temperature $\left({ }^{\circ} \mathrm{C}\right)$ & 16.6 & 16.0 \\
Minimum temperature $\left({ }^{\circ} \mathrm{C}\right)$ & 10.1 & 8.4 \\
Maximum extreme temperature $\left({ }^{\circ} \mathrm{C}\right)$ & 24.1 & 23.8 \\
Minimum extreme temperature $\left({ }^{\circ} \mathrm{C}\right)$ & 0.3 & -1.7 \\
Wind speed $(\mathrm{km} / \mathrm{h})$ & 0.4 & 0.5 \\
Maximum wind speed $(\mathrm{km} / \mathrm{h})$ & 11.0 & 11.0 \\
Dew point $\left({ }^{\circ} \mathrm{C}\right)$ & 9.7 & 8.7 \\
Maximum dew point $\left({ }^{\circ} \mathrm{C}\right)$ & 17.6 & 17.3 \\
Minimum dew point $\left({ }^{\circ} \mathrm{C}\right)$ & -18.1 & -21.3 \\
\hline
\end{tabular}

Follow-up carried out during a period of one year by meteorological stations (WatchDog model 2900ET) installed in each altitude level.

among climatic factors, which suffer alterations with altitude, such as atmospheric pressure, temperature, humidity, radiation and wind speed, only the atmospheric pressure is altered in a way that does not depend on the microclimate conditions of each environment.

Through the analysis of the results described in Table 1, it can be noted that, at $2100 \mathrm{~m}$ altitude, the average thickness of all $D$. brasiliensis leaf tissues were statistically lower than the ones at $1900 \mathrm{~m}$. It can be suggested that this reduction in thickness could favor the diffusion of $\mathrm{CO}_{2}$ in the leaves by the reduction in the routes to be run by this gas until the chloroplasts. This process would be even more facilitated by the increase in the abundance of intercellular spaces in the mesophyll of the leaves at $2100 \mathrm{~m}$ (Table 1), reducing the resistance in the intercellular spaces.

According to Taiz and Zeiger (2009), the main entrance routes for $\mathrm{CO}_{2}$ in the leaves during photosynthesis are the stomata and, after crossing this gap, $\mathrm{CO}_{2}$

Table 3 Gas exchanges of Drimys brasiliensis Miers leaves present at 1900 and $\mathbf{2 1 0 0 ~} \mathrm{m}$ altitude in a Montane Cloud Forest in Itamonte, MG, Brazil

\begin{tabular}{ccc}
\hline & $\mathbf{1 9 0 0}$ & $\mathbf{2 1 0 0}$ \\
\hline $\mathrm{g}_{\mathrm{s}}\left(\mathrm{mmol}_{\mathrm{CO} 2} \cdot \mathrm{m}^{-2} \cdot \mathrm{s}^{-1}\right)$ & $0.20 \mathrm{a}$ & $0.46 \mathrm{~b}$ \\
$\mathrm{Ci}(\mathrm{g} / \mathrm{mol})$ & $187.62 \mathrm{a}$ & $394.54 \mathrm{~b}$ \\
$\mathrm{E}(\mathrm{mmol}$ & $3.14 \mathrm{a}$ & $7.18 \mathrm{~b}$ \\
\hline
\end{tabular}

$\mathrm{g}_{\mathrm{s}}$, Stomatal conductance; $\mathrm{Ci}$, Internal carbon; $\mathrm{E}$, Transpiration rate. Means followed by the same letter in rows $(a, b)$ do not differ by the Scott-Knott test $(\mathrm{P}<0.05)$
Table 4 Stomatal analysis of Drimys brasiliensis Miers present at 1900 and $\mathbf{2 1 0 0}$ m altitude in a Montane Cloud Forest in Itamonte, MG, Brazil

\begin{tabular}{ccc}
\hline & $\mathbf{1 9 0 0}$ & $\mathbf{2 1 0 0}$ \\
\hline SE $(\mu \mathrm{m})$ & $19.09 \pm 0.81 \mathrm{a}$ & $18.89 \pm 0.74 \mathrm{a}$ \\
SP $(\mu \mathrm{m})$ & $26.67 \pm 1.48 \mathrm{a}$ & $26.49 \pm 2.20 \mathrm{a}$ \\
$\mathrm{SD}\left(\mathrm{stomata} / \mathrm{mm}^{2}\right)$ & $222.02 \pm 22.11 \mathrm{a}$ & $305.86 \pm 46.69 \mathrm{~b}$ \\
SI $(\%)$ & $14.56 \pm 0.99 \mathrm{a}$ & $18.91 \pm 2.70 \mathrm{~b}$ \\
SF $(\mathrm{SP} / \mathrm{SE})$ & $1.40 \pm 0.07 \mathrm{a}$ & $1.40 \pm 0.10 \mathrm{a}$ \\
\hline
\end{tabular}

SE, Stomatal equatorial diameter; SP, Stomatal polar diameter; SD, Stomatal density; SI, Stomatal index; SF, Stomatal functionality. All values are expressed as the mean \pm standard deviation. Means followed by the same letter in rows $(a, b)$ do not differ by the Scott-Knott test $(P<0.05)$.

needs to diffuse through the mesophyll until it finds the chloroplasts. The authors explain that each point on this route imposes resistance to the diffusion of $\mathrm{CO}_{2}$ in the leaves, and the main ones are: resistance of the borderline layer, stomatal resistance, resistance in intercellular spaces and resistance of the liquid phase.

Studies conducted by Nautiyal and Purohit (1980) with Artemisia sp. at two altitudes (550 and $3600 \mathrm{~m}$ ) evidenced that the elevation in altitude contributed to the reduction in leaf thickness. According to the authors, this reduction in leaf thickness would negatively affect the ability of the plants to avoid the beginning of hydric stress at higher altitudes; however, it could increase $\mathrm{CO}_{2}$ capture.

Analyzing cuticle thickness separately, $D$. brasiliensis leaves collected at $1900 \mathrm{~m}$ altitude presented a cuticle with approximately $12.43 \mu \mathrm{m}$, and the ones collected at $2100 \mathrm{~m}$, with $7.98 \mu \mathrm{m}$ (Table 1). The increase in cuticle thickness is a common adaptive response to species that grow in environments with high levels of radiation, such as the ones that survive at higher altitudes (Shepherd and Griffiths 2006; Jacobs et al. 2007). Due to this fact, considering the increase in radiation at $2100 \mathrm{~m}$ altitude isolately (Table 2), it was expected that, at this altitude level, $D$. brasiliensis leaves would present a higher cuticle thickness on the adaxial surface.

These results can be explained by a peculiar characteristic of cloud forests: the presence of constant fog at the vegetation level (Aldrich et al. 1997). It is known that in cloud forests of the Mantiqueira Mountains, Brazil, the fog occurs for about 65 to $90 \%$ of the days (Eller et al. 2013). At the level of $2100 \mathrm{~m}$ altitude, the environment presented a higher relative humidity than at $1900 \mathrm{~m}$ (Table 2) and the fog was possibly the most responsible factor for this increase, due to the frequency of its occurrence in cloud forests. Thus, despite the higher radiation levels at $2100 \mathrm{~m}$ altitude, the fog could act as a barrier against the direct penetration of solar beams in D. brasiliensis leaves at this altitude level, which would minimize the actual radiation falling upon the leaves 
and, in a way, it would reduce the need of protection performed by the cuticle.

Aldrich et al. (1997) explain that, in tropical montane cloud forests, the fog influences the vegetation because it reduces the incidence of solar radiation, causes the soaking of tree crowns and suppresses evapotranspiration. Future studies will be necessary to prove the real radiation rates that fall upon $D$. brasiliensis leaves, seeking a better comprehension of this interaction mechanism of the species with cloud forests.

\section{Chemical characterization of the essential oils from D. brasiliensis \\ Yield of the essential oils}

The yield of the essential oils from $D$. brasiliensis ranged from 0.03 to $1.02 \%$ (Table 5). Regardless drying, the leaves presented higher oil yields than the branches.

Ribeiro et al. (2008) evidenced a yield of approximately $0.97 \%$ for the essential oils from the leaves and stem barks from $D$. brasiliensis. Previously, Limberger et al. (2007), studying the essential oils from the species, noted that the yields ranged from 1.4 to $1.5 \%$ for the oils from fresh leaves, $1.0 \%$ for the oils from dry leaves, 0.4 to $0.6 \%$ for the oils from stem barks and $0.4 \%$ for the oils from unripe fruits. Gomes et al. (2013) found, for the same species, a yield of approximately $0.3 \%$ for the oil from fresh leaves.

No studies were found in the literature comparing the essential oils from $D$. brasiliensis in different altitudes. In this study, a trend for a higher oil yield was observed at $1900 \mathrm{~m}$ altitude (Table 5). According to Gobbo-Neto and Lopes (2007), the production of secondary metabolites in the plants can be influenced by different factors, such as seasonal conditions, temperature, radiation, hydric availability and atmospheric composition. It is known that many of these factors directly influence the development of the plants along altitudinal gradients (Körner 2007).

Vokou et al. (1993), while studying variations in the essential oils from Origanum vulgare subsp. hirtum Ietsw. in Greece showed that the highest yields of the oils were found for plants that grow at low altitudes.

Table 5 Yield of the essential oils from Drimys brasiliensis Miers present at 1900 and $\mathbf{2 1 0 0} \mathrm{m}$ altitude in a Montane Cloud Forest in Itamonte, MG, Brazil

\begin{tabular}{cccccccc}
\hline & \multicolumn{3}{c}{$\mathbf{1 9 0 0}$} & & \multicolumn{3}{c}{$\mathbf{2 1 0 0}$} \\
\cline { 2 - 4 } \cline { 8 - 9 } Plant material & FF & FS & G & & FF & FS & G \\
\hline Mass (g) & 55.77 & 36.24 & 80.05 & & 55.77 & 35.16 & 80.03 \\
Humidity (\%) & 67.00 & 0.00 & 50.50 & & 53.00 & 0.00 & 51.50 \\
*Yield (\% p/p HFB) & 0.92 & 1.02 & 0.03 & & 0.48 & 0.80 & 0.03
\end{tabular}

FF, Fresh leaves; FS, Dry leaves; G, Fresh branches; HFB, Humidity free base. "Yield = Yield average of the oils from 4 individuals of $D$. brasiliensis/ altitude level.
Studies conducted by Kizil (2010) evidenced similar results for Thymbra spicata var. spicata L. in some regions in Turkey. These results were attributed to the higher temperatures in the regions with a lower altitude.

According to Gobbo-Neto and Lopes (2007), the production of essential oils seems to be favored by higher temperatures, although too high temperatures lead to an excessive loss of these metabolites. Thus, based on the literature, it is possible to suggest that the production of essential oils from $D$. brasiliensis may have been favored by the higher temperatures at $1900 \mathrm{~m}$ altitude (Table 2), where the species presented a trend to a higher yield of the essential oils from fresh and dry leaves (Table 5). New studies with the species at controlled microclimate conditions may support this hypothesis.

\section{Chemical composition of the essential oils}

Fifty-nine chemical compounds have been identified, representing from 92.81 to $98.75 \%$ of the constitution of the essential oils from $D$. brasiliensis (Table 6). The major compounds were hinesol, $\beta$-eudesmol, $\alpha$-eudesmol, elemol, epi-cyclocolorenone, $\alpha$-pinene and safrole (Figure 3; Table 6). There was the predominance of sesquiterpenes in all oils, and the highest values were found for the oils from fresh branches at $1900 \mathrm{~m}$ altitude (81.46\%). The drimanic sesquiterpenes drimenol and polygodial, common for Drimys oils (Cicció 1997; Malheiros et al. 2001; Muñoz-Concha et al. 2007), were not detected.

Lago et al. (2010) evidenced the predominance of sesquiterpenes in the oils from $\mathrm{D}$. brasiliensis leaves (52.31\%) collected in Campos do Jordão, SP, Brazil, and the major constituents were $\alpha$-cedrene $(6.87 \%)$, bicyclogermacrene (5.31\%), t-muurolol (7.75\%) and drimenol (9.96\%). In the oils from the stem barks, the authors showed that monoterpenes were present in higher proportions (90.02\%). Ribeiro et al. (2008) also observed the predominance of sesquiterpenes $(66.0 \%)$ in the oils from fresh leaves and stem barks from $D$. brasiliensis collected in Rio Grande do Sul, Brazil. Studies conducted by Limberger et al. (2007) showed that in the oils from fresh and dry leaves of $D$. brasiliensis, equivalent contents of monoterpenes (31.2\% to $53.9 \%)$ and sesquiterpenes $(37.1 \%$ to $65.4 \%)$ were found and, in the oils from fruits and stem barks, sesquiterpenes were predominant (75.5\% to $93.4 \%)$.

In addition to sesquiterpenes, monoterpenes and phenylpropanoids were also found in the essential oils from leaves and branches of D. brasiliensis (Table 6). The formation of sesquiterpenes and monoterpenes occurred by the mevalonic acid and the 1-deoxy-D-xylulose-5-phosphate (DXPS) biosynthetic pathways, while the formation of phenylpropanoids occurred by the shikimic acid pathway (Solomons and Fryhle 2002). The highest proportions of monoterpenes were found in the oils from 
Table 6 Chemical composition of Drimys brasiliensis Miers essential oils present at 1900 and 2100 m altitude in a Montane Cloud Forest in Itamonte, MG, Brazil

\begin{tabular}{|c|c|c|c|c|c|c|c|c|c|c|}
\hline & Compound & RT & TKI & CKI & FF $1900(\%)$ & FF $2100(\%)$ & FS $1900(\%)$ & FS 2100 (\%) & G 1900 (\%) & G 2100 (\%) \\
\hline & Monoterpene Hydrocarbons & & & & 13.63 & 9.73 & 21.53 & 19.03 & 11.76 & 7.30 \\
\hline 1 & a-Thujone & 6.499 & 924 & 939 & 0.17 & 0.03 & 0.29 & 0.15 & 0.03 & - \\
\hline 2 & a-Pinene & 6.745 & 932 & 945 & 8.39 & 6.12 & 13.27 & 11.54 & 9.84 & 6.20 \\
\hline 3 & Camphene & 7.186 & 946 & 955 & - & 0.02 & 0.08 & 0.04 & - & - \\
\hline 4 & Sabinene & 7.926 & 969 & 973 & 0.53 & 0.55 & 0.86 & 1.11 & 0.28 & 0.17 \\
\hline 5 & $\beta$-Pinene & 8.070 & 974 & 977 & 1.96 & 1.50 & 3.02 & 2.73 & 1.53 & 0.93 \\
\hline 6 & Myrcene & 8.425 & 988 & 985 & 0.47 & 0.25 & 0.76 & 0.62 & - & - \\
\hline 7 & a-Terpinene & 9.402 & 1014 & 1010 & 0.32 & 0.15 & 0.53 & 0.42 & - & - \\
\hline 8 & $\rho$-Cymene & 9.701 & 1020 & 1019 & 0.33 & 0.11 & 0.17 & 0.25 & - & - \\
\hline 9 & o-Cymene & 9.705 & 1022 & 1019 & - & - & 0.36 & - & - & - \\
\hline 10 & Limonene & 9.866 & 1024 & 1023 & 0.56 & 0.39 & 0.25 & - & 0.08 & - \\
\hline 11 & Sylvestrene & 9.869 & 1025 & 1023 & - & - & 0.44 & 1.03 & - & - \\
\hline 12 & $Y$-Terpinene & 11.029 & 1054 & 1056 & 0.73 & 0.44 & 1.16 & 0.66 & - & - \\
\hline 13 & Terpinolene & 12.252 & 1086 & 1091 & 0.17 & 0.17 & 0.34 & 0.48 & - & - \\
\hline & Oxygenated Monoterpenes & & & & 2.33 & 1.29 & 2.45 & 1.91 & 5.53 & 3.19 \\
\hline 14 & 1,8-Cineole & 9.990 & 1026 & 1027 & - & - & 0.08 & 0.15 & - & - \\
\hline 15 & Linalool & 12.715 & 1095 & 1103 & - & - & - & - & 0.07 & - \\
\hline 16 & Camphor & 14.754 & 1146 & 1149 & - & - & 0.06 & - & 0.08 & 0.04 \\
\hline 17 & Terpinen-4-ol & 16.220 & 1174 & 1182 & 1.92 & 1.00 & 2.16 & 1.38 & 3.64 & 1.29 \\
\hline 18 & p-Cimen-8-ol & 16.591 & 1179 & 1190 & - & - & - & - & - & 0.21 \\
\hline 19 & a-Terpineol & 16.827 & 1186 & 1201 & 0.41 & 0.29 & 0.15 & 0.38 & 1.74 & 1.65 \\
\hline & Sesquiterpene Hydrocarbons & & & & 2.99 & 7.48 & 7.27 & 14.48 & 0.07 & 0.25 \\
\hline 20 & $\beta$-Elemene & 25.869 & 1389 & 1396 & 0.21 & 0.20 & 0.19 & 0.46 & - & - \\
\hline 21 & a-Funebrene & 26.415 & 1402 & 1409 & - & - & 0.15 & 0.15 & - & - \\
\hline 22 & a-Gurjunene & 26.702 & 1409 & 1415 & - & 0.54 & - & 1.94 & - & - \\
\hline 23 & a-Cedrene & 26.857 & 1410 & 1419 & - & - & - & 0.11 & - & - \\
\hline 24 & (E)-Caryophyllene & 27.135 & 1417 & 1425 & - & - & 1.11 & 0.55 & - & - \\
\hline 25 & $\beta$-Caryophyllene & 27.137 & 1417 & 1425 & 0.60 & 0.40 & - & - & - & - \\
\hline 26 & a-trans-Bergamotene & 27.736 & 1432 & 1439 & - & - & - & 0.09 & - & - \\
\hline 27 & Aromadendrene & 27.979 & 1439 & 1445 & - & - & 0.13 & - & - & - \\
\hline 28 & cis-Muurola-3,5-diene & 28.452 & 1448 & 1456 & - & - & - & 0.08 & - & - \\
\hline 29 & a-Humulene & 28.617 & 1452 & 1460 & - & - & 0.39 & 0.18 & - & - \\
\hline 30 & (E)- $\beta$-Farnesene & 28.630 & 1454 & 1460 & - & 0.48 & - & 0.37 & - & - \\
\hline 31 & (E)-9-epi-Caryophyllene & 28.940 & 1464 & 1467 & - & - & - & 0.13 & - & - \\
\hline 32 & trans-Cadina-1(6),4-diene & 29.441 & 1475 & 1479 & - & - & - & 0.16 & - & - \\
\hline 33 & Y-Curcumene & 29.644 & 1481 & 1483 & 0.35 & 2.86 & 2.36 & 5.32 & - & 0.12 \\
\hline 34 & $\beta$-Selinene & 30.044 & 1489 & 1493 & - & - & 0.30 & 0.09 & - & - \\
\hline 35 & trans-Muurola-4(14),5-diene & 30.311 & 1493 & 1499 & - & - & - & 0.17 & - & - \\
\hline 36 & Bicyclogermacrene & 30.484 & 1500 & 1503 & 1.69 & 2.03 & 2.30 & 2.73 & 0.07 & 0.13 \\
\hline 37 & $\beta$-Curcumene & 30.995 & 1514 & 1515 & - & 0.55 & 0.26 & 0.68 & - & - \\
\hline 38 & 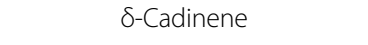 & 31.543 & 1522 & 1529 & 0.14 & 0.42 & 0.08 & 1.14 & - & - \\
\hline 39 & Zonarene & 31.664 & 1528 & 1532 & - & - & - & 0.13 & - & - \\
\hline
\end{tabular}


Table 6 Chemical composition of Drimys brasiliensis Miers essential oils present at 1900 and 2100 m altitude in a Montane Cloud Forest in Itamonte, MG, Brazil (Continued)

\begin{tabular}{|c|c|c|c|c|c|c|c|c|c|c|}
\hline & Oxygenated Sesquiterpenes & & & & 74.62 & 59.92 & 56.56 & 50.23 & 81.39 & 73.90 \\
\hline 40 & Elemol & 32.749 & 1548 & 1558 & 6.72 & 6.08 & 4.62 & 4.60 & 9.91 & 4.01 \\
\hline 41 & (E)-Nerolidol & 33.127 & 1561 & 1568 & - & 0.15 & 0.10 & - & - & 0.09 \\
\hline 42 & Palustrol & 33.487 & 1567 & 1577 & - & 0.22 & - & 0.35 & - & 0.03 \\
\hline 43 & Spathulenol & 33.916 & 1577 & 1587 & 0.70 & 1.06 & 0.68 & 0.86 & 1.65 & 3.23 \\
\hline 44 & Viridiflorol & 34.509 & 1592 & 1602 & - & 1.02 & - & 0.53 & 0.25 & 0.18 \\
\hline 45 & Ledol & 34.942 & 1602 & 1613 & - & - & - & 0.16 & - & - \\
\hline 46 & 10-epi-y-Eudesmol & 35.615 & 1622 & 1630 & 0.45 & 0.29 & 0.10 & 0.19 & 0.09 & - \\
\hline 47 & $\beta$-Acorenol & 36.023 & 1636 & 1640 & - & - & - & - & - & 0.91 \\
\hline 48 & Hinesol & 36.290 & 1640 & 1647 & 21.42 & 15.20 & 15.85 & 11.91 & 20.61 & 8.73 \\
\hline 49 & a-Cadinol & 36.954 & 1652 & 1664 & - & - & - & 0.20 & - & - \\
\hline 50 & $\beta$-Eudesmol & 37.016 & 1649 & 1665 & 26.16 & 15.92 & 19.63 & 12.70 & 29.27 & 11.10 \\
\hline 51 & a-Eudesmol & 37.112 & 1652 & 1668 & 19.17 & 13.53 & 15.37 & 10.78 & 19.61 & 8.69 \\
\hline 52 & Epi- $\beta$-Bisabolol & 37.456 & 1670 & 1676 & - & 0.92 & 0.21 & 0.63 & - & 0.31 \\
\hline 53 & $\beta$-Bisabolol & 37.459 & 1674 & 1677 & - & - & - & - & - & 0.15 \\
\hline \multirow[t]{2}{*}{54} & Epi-Cyclocolorenone & 41.114 & 1774 & 1775 & - & 5.53 & - & 7.32 & - & 36.47 \\
\hline & Phenylpropanoids & & & & 2.02 & 14.39 & 7.11 & 7.48 & 0.00 & 8.95 \\
\hline 55 & Safrole & 21.334 & 1285 & 1295 & 1.87 & 11.84 & 5.42 & 7.48 & - & 5.04 \\
\hline 56 & Eugenol & 24.435 & 1356 & 1364 & - & - & 0.34 & - & - & 0.12 \\
\hline 57 & Methyl Eugenol & 26.439 & 1403 & 1409 & 0.15 & - & - & - & - & - \\
\hline 58 & Myristicin & 31.658 & 1517 & 1532 & - & 2.55 & 1.35 & - & - & 2.94 \\
\hline \multirow[t]{2}{*}{59} & 2,6-Dimethoxy-4-allylphenol & 34.956 & * & 1613 & - & - & - & - & - & 0.85 \\
\hline & Total identified (\%) & & & & 95.59 & 92.81 & 94.92 & 93.13 & 98.75 & 93.59 \\
\hline
\end{tabular}

RT, retention time in minutes provided by GC-MS; TKI, tabulated Kovats index (Adams, 2007); CKI, calculated Kovats index; FF, fresh leaf oils; FS, dry leaf oils; G, fresh branch oils; \%, percentage of the component. " Source: WILEY8.

dry leaves $(23.98 \%$ at $1900 \mathrm{~m}$ and $20.94 \%$ at $2100 \mathrm{~m}$ altitude) (Table 6). Phenylpropanoids seem to be the constituents that most responded to the elevation in altitude. In the fresh leaves and in the fresh branches, this response was even more evident, because at $1900 \mathrm{~m}$, phenylpropanoids were identified in the proportions of $2.02 \%$ and $0 \%$, respectively. At $2100 \mathrm{~m}$, the proportions increased to $14.39 \%$ and $8.95 \%$ (Table 6). It is thus inferred that the elevation in altitude favored the biosynthesis of these compounds in D. brasiliensis.

A great part of phenylpropanoids is derived from the cinnamic acid, which is formed from the phenylalanine amino acid by the deamination activity of phenylalanine ammonia-lyase (PAL) (Dixon and Paiva 1995; Dixon et al. 2002; Ziaei et al. 2012). Phenylalanine ammonialyase plays a fundamental role in the regulation of the production of phenylpropanoids in plants. It is known that many factors, such as plant age, herbivores, UV radiation and low temperatures, affect its biosynthesis and, consequently, the synthesis of phenylpropanoids (Ziaei et al., 2012).
Many phenylpropanoids are produced in response to any biotic or abiotic stress. The biosynthesis of some of these compounds is stimulated in injured plants and plants under the attack of herbivores. Others, such as anthocyanins and flavonoids, increase their concentrations in response to higher rates of visible and UV radiation. The biosynthesis of many of them is favored by low temperatures and nutritional stress; however, the influence of these factors on the production of phenylpropanoids is not certain yet (Dixon and Paiva 1995).

It is important to point out that, most of the times, the production of secondary metabolites in plants is influenced by different factors acting together (GobboNeto and Lopes 2007). Thus, it is proposed that the temperature is possibly one of the factors that might influence the chemical composition of the essential oils from $D$. brasiliensis. The lower temperatures at $2100 \mathrm{~m}$ altitude (Table 2), might have probably favored the route of the phenylpropanoids.

In this study, the phenylpropanoids identified were safrole, eugenol, methyl eugenol, myristicin and 2,6- 


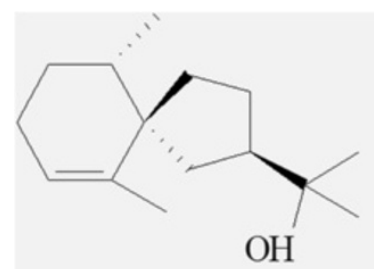

a

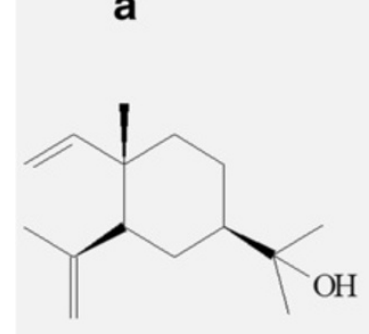

d<smiles>C=C1CCCC2(C)CCC(C(C)(C)O)C[C@H]12</smiles>

b<smiles>CC1=C2C(CCC(C)C2C(C)C)C(C)C1=O</smiles>

e

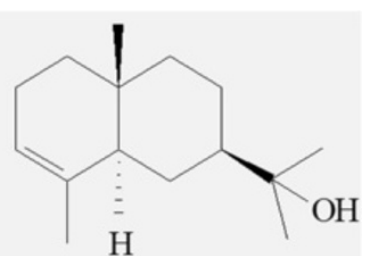

C

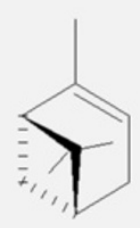

$\mathbf{f}$

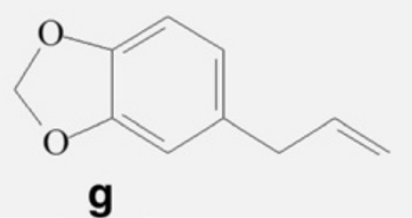

Figure 3 Chemical structures of the major constituents in the essential oils from Drimys brasiliensis Miers. (a) Hinesol; (b) $\beta$-Eudesmol; (c) a-Eudesmol; (d) Elemol; (e) Epi-Cyclocolorenone; (f) a-Pinene; (g) Safrole.

dimethoxy-4-allylphenol (Table 6). Except for 2,6dimethoxy-4-allylphenol, all these compounds have already been found in the essential oils from $D$. brasiliensis (Limberger et al. 2007; Ribeiro et al. 2008; Lago et al. 2010; Gomes et al. 2013).

\section{Principal Component Analysis (PCA)}

The analysis of the essential oils through the PCA technique showed that, with the first principal component and the second principal component, it was possible to describe $96.85 \%$ of the data, considering $81.27 \%$ of total variance described by the first principal component (Figure 4). PCA allows separating the volatile oils from D. brasiliensis in three groups, which express the similarities and the differences of these oils in relation to their chemical constituents.

Observing Figure 4, it can be seen that the oils from the fresh branches at $2100 \mathrm{~m}$ altitude are different from the other groups by the compound 54, epicyclocolorenone, a sesquiterpene ketone (Figure 3e). Epi-cyclocolorenone was biosynthesized only at $2100 \mathrm{~m}$ altitude in all oils, and in higher proportions in the oils from fresh branches (36.47\%), followed by dry leaves $(7.32 \%)$ and fresh leaves (5.53\%) (Table 6). Thus, it can be

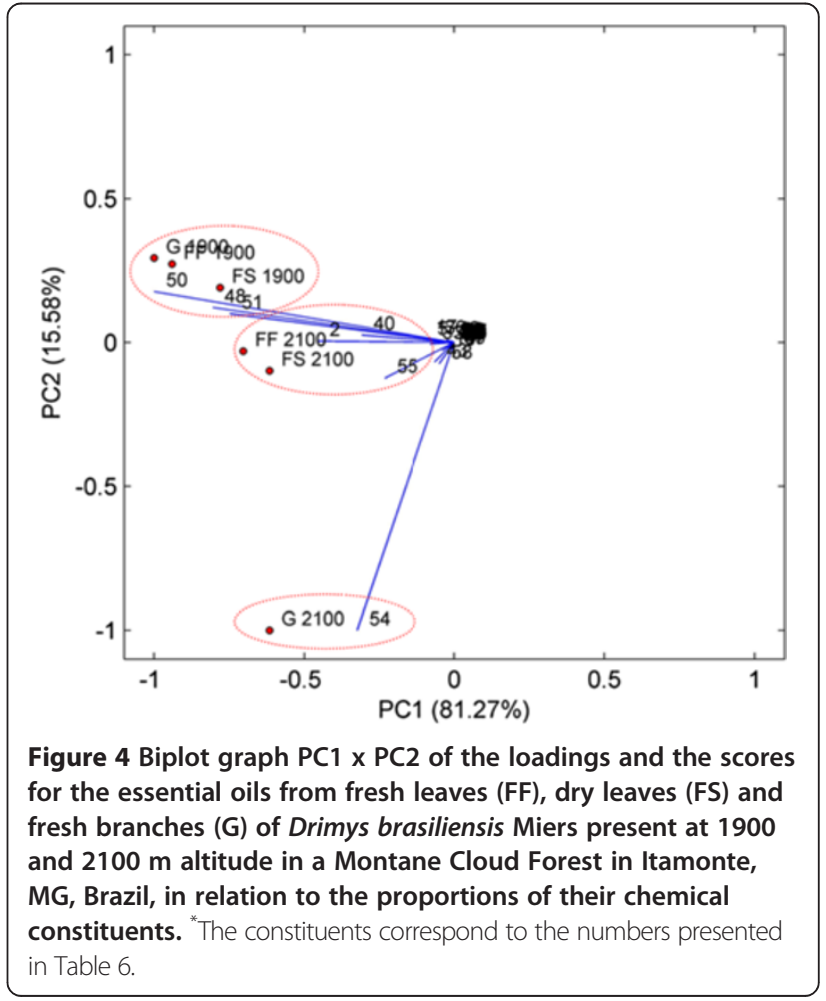


seen that the elevation in altitude favored the biosynthesis of this compound in D. brasiliensis, in addition to favoring the formation of phenylpropanoids. It can also be inferred that epi-cyclocolorenone, possibly, presents biosynthesis in the branches and is translocated to the leaves.

Studies by Limberger et al. (2007), Ribeiro et al. (2008) and Gomes et al. (2013) evidence the presence of cyclocolorenone as a major constituent of the oils from $D$. brasiliensis. Epi-cyclocolorenone is different from cyclocolorenone only by the presence of a 1,1dimethylcyclopropane group oriented backwards. Cyclocolorenone occurs rarely in nature and it has already been reported in Pseudowintera colorata (Raoul) Dandy and Tasmannia sp., belonging to the Winteraceae family, in addition to Solidago canadensis L. (Asteraceae), Ledum palustre L. (Ericaceae) and Magnolia grandiflora L. (Magnoliaceae) (Ribeiro et al. 2008).

The oils from the fresh and dry leaves at $2100 \mathrm{~m}$ altitude were separated by the presence of the compounds 2, 40 and 55 ( $\alpha$-pinene, elemol and safrole) (Figure 3f, d, g; Figure 4). It can be highlighted that safrole was biosynthesized in the leaves in higher proportions at $2100 \mathrm{~m}$ altitude and, in the branches, it was formed only at $2100 \mathrm{~m}$ (Table 6), evidencing that the elevation in altitude favored the production of phenylpropanoids in D. brasiliensis.

The other group was formed by all oils from $D$. brasiliensis at $1900 \mathrm{~m}$ altitude, separated by the compounds 48, 50 and 51, hinesol, $\beta$-eudesmol and $\alpha$-eudesmol, respectively (Figure 3a, b, c; Figure 4). These constituents are classified as tertiary sesquiterpene alcohols, characterized by the presence of one hydroxyl group connected to one tertiary carbon (Solomons and Fryhle 2002) and they were biosynthesized in higher proportions at $1900 \mathrm{~m}$ altitude in all essential oils (Table 6). These results confirm the predominance of the sesquiterpenes in the oils from the species.

The presence of these sesquiterpene alcohols among the major constituents of the oils from $D$. brasiliensis becomes relevant due to the diversity of biological potentialities already described for these compounds. Miyazawa et al. (1996) demonstrated the antimutagenic potential of $\beta$-eudesmol extracted from Dioscorea japonica Thunb. (Dioscoreaceae) rhizomes. Recent studies by Jalali et al. (2013), mentioned that $\alpha$-eudesmol demonstrated to be a compound able to induce apoptosis in tumor cells. In addition, Ouyang et al. (2012) mentioned that hinesol proved to be a compound that inhibits gastric secretion in rats. This compound also proved able to improve the circulation and metabolism of the brain.

\section{Conclusions}

D. brasiliensis presented a high phenotypic plasticity at the altitude levels studied. In relation to its leaf anatomy, the species showed adaptive characteristics, which can maximize the absorption of $\mathrm{CO}_{2}$ at $2100 \mathrm{~m}$ altitude, where a reduction in the partial pressure of this atmospheric gas occurs. These characteristics were the formation of papillae on the abaxial surface of the leaves, an increase in the stomatal density and index, a reduction in leaf tissue thickness, an increase in the abundance of intercellular spaces in the mesophyll and an increase in stomatal conductance and in carbon accumulation in the leaves.

The essential oils from $D$. brasiliensis presented yields between 0.03 and $1.02 \%$, and the highest values were found for the leaves. Fifty-nine chemical constituents were identified in the oils, with the predominance of sesquiterpenes. Two trends could be inferred for the species in relation to its secondary metabolism and the altitude. The biosyntheses of sesquiterpene alcohols at $1900 \mathrm{~m}$, and phenylpropanoids and epi-cyclocolorenone at $2100 \mathrm{~m}$, were favored.

This research stimulates new studies that investigate the adaptive characteristics of $D$. brasiliensis in altitudinal forests. In addition, its essential oils presented promising compounds for the future evaluation of biological potentialities.

\section{Competing interests}

The authors declare that they have no competing interests.

\section{Authors' contributions}

BPC, EMC and MGC planned the study, analyzed the data and developed the paper. SMFM carried out the chromatographic analyses. KFS, PVP and MALF participated in the collection of the plant material. All authors read and approved the final manuscript.

\section{Acknowledgements}

This research was supported by Universidade Federal de Lavras, Fundação de Amparo à Pesquisa do Estado de Minas Gerais and Conselho Nacional de Desenvolvimento Científico e Tecnológico. The authors are grateful to RPPN Alto-Montana for the availability.

\section{Author details}

'Departamento de Biologia, Universidade Federal de Lavras, Campus Universitário, PO Box 3037, CEP 37200-000, Lavras, MG, Brazil. ²Departamento de Química, Universidade Federal de Lavras, Campus Universitário, PO Box 3037, CEP 37200-000, Lavras, MG, Brazil. ³Departamento de Química, Universidade Federal de Sergipe, Avenida Marechal Rondon, s/n, CEP 49100-000, São Cristóvão, SE, Brazil. ${ }^{4}$ Departamento de Ciências Florestais, Universidade Federal de Lavras, Campus Universitário, PO Box 3037, CEP 37200-000, Lavras, MG, Brazil.

Received: 11 December 2013 Accepted: 1 April 2014 Published: 10 May 2014

\section{References}

Adams RP (2007) Identification of essential oils components by gas chromatography/mass spectroscopy, 4th edn. Allured, Carol Stream Aldrich M, Billington C, Edwards M, Laidlaw R (1997) Tropical montane cloud forests: an urgent priority for conservation, n 2. World Conservation Monitoring Centre, Biodiversity Bulletin, Cambridge

Bertoncello R, Yamamoto K, Meireles LD, Shepherd GJ (2011) A phytogeographic analysis of cloud forests and other forest subtypes amidst the Atlantic forests in south and southeast Brazil. Biodivers Conserv 20:3413-3433

Brasil. Agência Nacional de Vigilância Sanitária (2010) Farmacopeia brasileira, vol 1, 5th edn. Anvisa, Brasília, pp 198-199 
Brewer CA, Smith WK (1997) Patterns of leaf surface wetness for montane and subalpine plants. Plant Cell Environ 20:1-11

Cicció JF (1997) Aceites esenciales de las hojas y de los frutos verdes de Drimys granadensis (Winteraceae). Rev Biol Trop 44:29-33

Dixon RA, Paiva NL (1995) Stress-Induced phenylpropanoid metabolism. Plant Cell 7:1085-1097

Dixon RA, Achnine L, Kota P, Liu CJ, Reddy MSS, Wang L (2002) The phenylpropanoid pathway and plant defence-a genomics perspective. Mol Plant Pathol 3:371-390

Ehrendorfer F, Silberbauer-Gottsberger I, Gottsberger G (1979) Variation on the population, racial, and species level in the primitive relic angiosperm genus Drimys (Winteraceae) in South America. Plant Syst Evol 132:53-83

Eller CB, Lima AL, Oliveira RS (2013) Foliar uptake of fog water and transport belowground alleviates drought effects in the cloud forest tree species, Drimys brasiliensis (Winteraceae). New Phytol 199:151-162

Esau K (1974) Anatomia das plantas com sementes. Editora Blucher, São Paulo

Feder N, O'Brien TP (1968) Plant microtechnique: some principles and new methods. Amer J Bot 55:123-142

Feild TS, Zwieniecki MA, Donoghue MJ, Holbrook NM (1998) Stomatal plugs of Drimys winteri (Winteraceae) protect leaves from mist but not drought. Proc Natl Acad Sci U S A 95:14256-14259

Feild TS, Zwieniecki MA, Holbrook NM (2000) Winteraceae evolution: an ecophysiological perspective. Ann Missouri Bot Gard 87:323-334

Ferreira DF (2003) SISVAR: versão 4.6 (Build 61), software. UFLA/DEX, Lavras

Fiqueiredo ACS, Barroso JMG, Pedro LMG, Ascensão L (2007) Histoquímica e citoquímica em plantas: princípios e protocolos, 1st edn. Faculdade de Ciências da Universidade de Lisboa, Centro de Biotecnologia Vegetal, Lisboa

Gobbo-Neto L, Lopes NP (2007) Plantas medicinais: fatores de influência no conteúdo de metabólitos secundários. Quim Nova 30:374-381

Gomes MRF, Schuh RS, Jacques ALB, Augustin OA, Bordignon SAL, Dias DO, Kelmann RG, Koester LS, Gehring MP, Morrone FB, Campos MM, Limberger RP (2013) Citotoxic activity evaluation of essential oils and nanoemulsions of Drimys angustifolia and D. brasiliensis on human glioblastoma (U-138 MG) and human bladder carcinoma (T24) cell lines in vitro. Rev Bras Farmacogn 23:259-267

Guimarães LGL, Cardoso MG, Zacaroni LM, Lima RK, Pimentel FA, Morais AR (2008) Influência da luz e da temperatura sobre a oxidação do óleo essencial de capim-limão (Cymbopogon citratus (D.C.) Stapf). Quim Nova 31:1476-1480

Jacobs JF, Koper GJM, Ursem WNJ (2007) UV protective coatings: a botanical approach. Prog Org Coat 58:166-171

Jalali HT, Petronilho S, Villaverde JJ, Coimbra MA, Domingues MRM, Ebrahimian ZJ, Silvestre AJD, Rocha SM (2013) Assessment of the sesquiterpenic profile of Ferula gummosa oleo-gum-resin (galbanum) from Iran. Contributes to its valuation as a potential source of sesquiterpenic compounds. Ind Crops Prod 44:185-191

Joly CA (2007) Biodiversidade e mudanças climáticas: contexto evolutivo, histórico e político. Ambient Soc 10:169-172

Kizil S (2010) Determination of essential oil variations of Thymbra spicata var. spicata L. naturally growing in the wild flora of East Mediterranean and Southeastern Anatolia regions of Turkey. Ind Crops Prod 32:593-600

Kofidis G, Bosabalidis AM (2008) Effects of altitude and season on glandular hairs and leaf structural traits of Nepeta nuda L. Bot Stud 49:363-372

Kofidis G, Bosabalidis AM, Moustakas M (2007) Combined effects of altitude and season on leaf characteristics of Clinopodium vulgare L. (Labiatae). Environ Exp Bot 60:69-76

Körner C (2007) The use of 'altitude' in ecological research. Trends Ecol Evol 22:569-574

Körner C, Cochrane PM (1985) Stomatal responses and water relations of Eucalyptus paucitlora in summer along an elevational gradient. Oecologia 66:443-455

Kouwenberg LLR, Kürschner WM, McElwain JC (2007) Stomatal frequency change over altitudinal gradients: prospects for paleoaltimetry. Rev Mineral Geochem $66: 215-241$

Kraus JE, Arduin M (1997) Manual básico de métodos em morfologia vegetal. EDUR, Seropédica

Lago JHG, Carvalho LAC, Silva FS, Toyama DO, Fávero OA, Romoff P (2010) Chemical composition and anti-inflammatory evaluation of essential oils from leaves and stem barks from Drimys brasiliensis Miers (Winteraceae). J Braz Chem Soc 21:1760-1765

Li C, Zhang X, Liu X, Luukkanen O, Berninger F (2006) Leaf morphological and physiological responses of Quercus aquifolioides along an altitudinal gradient. Silva Fenn 40:5-13
Limberger RP, Scopel M, Sobral M, Henriques AT (2007) Comparative analysis of volatiles from Drimys brasiliensis Miers and D. angustifolia Miers (Winteraceae) from Southern Brazil. Biochem Syst Ecol 35:130-137

Lorenzi H, Matos FJA (2008) Plantas medicinais no Brasil: nativas e exóticas, 2nd edn. Instituto Plantarum, Nova Odessa, p 538

Malheiros A, Cechinel Filho V, Schmitt CB, Santos ARS, Scheidt C, Calixto JB, Monache FD, Yunes RA (2001) A sesquiterpene drimane with antinociceptive activity from Drimys winteri bark. Phytochemistry 57:103-107

Marquínez X, Lohmann LG, Salatino MLF, Salatino A, González F (2009) Generic relationships and dating of lineages in Winteraceae based on nuclear (ITS) and plastid (rpS16 and psbA-trnH) sequence data. Mol Phyl Evol 53:435-449

Meireles LD, Shepherd GJ, Kinoshita LS (2008) Variações na composição florística e na estrutura fitossociológica de uma floresta ombrófila densa alto-montana na Serra da Mantiqueira, Monte Verde, MG. Rev Bras Bot 31:559-574

Metcalfe CR, Chalk L (1957) Anatomy of the dicotyledons, vol 1. Oxford University Press, London, pp 25-30

Miyazawa M, Shimamura H, Nakamura SI, Kameoka H (1996) Antimutagenic activity of (+)- $\beta$-eudesmol and paeonol from Dioscorea japonica. J Agric Food Chem 44:1647-1650

Muñoz-Concha D, Vogel H, Yunes R, Razmilic I, Bresciani L, Malheiros A (2007) Presence of polygodial and drimenol in Drimys populations from Chile. Biochem Syst Ecol 35:434-438

Nautiyal S, Purohit AN (1980) High altitude acclimatization in plants: stomatal frequency and anatomical changes in leaves of Artemisia species. Biol Plant 22:282-286

Nunes CA, Freitas MP, Pinheiro ACM, Bastos SC (2012) Chemoface: a novel free user-friendly interface for chemometrics. J Braz Chem Soc 23:2003-2010

Ouyang Z, Zhang L, Zhao M, Wang P, Wei Y, Fang J (2012) Identification and quantification of sesquiterpenes and polyacetylenes in Atractylodes lancea from various geographical origins using GC-MS analysis. Rev Bras Farmacogn 22:957-963

Pane E, Pereira SY (2005) As fontes em Itamonte, sul de Minas Gerais - uma contribuição para o entendimento das relações entre água superficial e subterrânea. Águas Subterrâneas 19:1-14

Pereira FJ, Castro EM, Oliveira C, Pires MF, Pasqual M (2011) Mecanismos anatômicos e fisiológicos de plantas de aguapé para a tolerância à contaminação por arsênio. Planta Daninha 29:259-267

Pimentel FA, Cardoso MG, Zacaroni LM, Andrade MA, Guimarães LGL, Salgado APSP, Freire JM, Muniz FR, Morais AR, Nelson DL (2008) Influência da temperatura de secagem sobre o rendimento e a composição química do óleo essencial de Tanaecium nocturnum (Barb. Rodr.) Bur. \& K. Shum. Quim Nova 31:523-526

Read C, Menary R (2000) Analysis of the contents of oil cells in Tasmannia lanceolata (Poir.) A. C. Smith (Winteraceae). Ann Bot 86:1193-1197.

Ribeiro VLS, Rolim V, Bordignon S, Henriques AT, Dorneles GG, Limberger RP, von Poser G (2008) Chemical composition and larvicidal properties of the essential oils from Drimys brasiliensis Miers (Winteraceae) on the cattle tick Rhipicephalus (Boophilus) microplus and the brown dog tick Rhipicephalus sanguineus. Parasitol Res 102:531-535

Sá Júnior A, Gonsaga LC, Silva FF, Alves MC (2012) Application of the Köppen classification for climatic zoning in the state of Minas Gerais, Brazil. Theor Appl Climatol 108:1-7

Shepherd T, Griffiths DW (2006) The effects of stress on plant cuticular waxes. New Phytol 171:469-499

Smith AC (1943) The American species of Drimys. J Arnold Arbor 24:1-33

Solomons TWG, Fryhle CB (2002) Química orgânica, 7th edn. Livros Técnicos e Científicos, Rio de Janeiro

Souza VC, Lorenzi H (2008) Botânica sistemática: guia ilustrado para identificação das famílias de fanerógamas nativas e exóticas no Brasil, baseado em APG II, 2nd edn. Instituto Plantarum, Nova Odessa, p 76

Taiz L, Zeiger E (2009) Fisiologia vegetal, 4th edn. Artmed, Porto Alegre, pp 234-239

van den Dool H, Kratz PD (1963) A generalization of the retention index system including liner temperature programmed gas-liquid partition chromatography. J Chromatogr 11:463-471

Veloso HP, Rangel Filho ALR, Lima JCA (1991) Classificação da vegetação brasileira adaptada a um sistema universal. IBGE, Rio de Janeiro, p 123

Vieira RC, Gomes DMS (1995) Superfície da lâmina foliar de Psychotria nuda (Cham. \& Schltdl.) Wawra, P. leiocarpa Cham. \& Schltdl., P. stenocalyx Müll. Arg. e P. tenuinervis Müll. Arg. (Rubiaceae). Acta Bot Bras 9:263-270

Vokou D, Kokkini S, Bessiere JM (1993) Geographic variation of Greek Oregano (Origanum vulgare ssp. hirtum) essential oils. Biochem Syst Ecol 21:287-295 
West WC (1969) Ontogeny of oil cells in the woody Ranales. Bull Torrey Bot Club 96:329-344

Woodward FI (1986) Ecophysiological studies on the shrub Vaccinium myrtillus L. taken from a wide altitudinal range. Oecologia 70:580-586

Zarinkamar F, Tajik S, Soleimanpour S (2011) Effects of altitude on anatomy and concentration of crocin, picrocrocin and safranal in Crocus sativus L. Aust J Crop Sci 5:831-838

Zhao C, Chen L, Ma F, Yao B, Liu J (2008) Altitudinal differences in the leaf fitness of juvenile and mature alpine spruce trees (Picea crassifolia). Tree Physiol 28:133-141

Zhou Y, Schaub M, Shi L, Guo Z, Fan A, Yan C, Wang X, Wang C, Han SJ, Li MH (2012) Non-linear response of stomata in Pinus koraiensis to tree age and elevation. Trees 26:1389-1396

Ziaei M, Sharifi M, Behmanesh M, Razavi K (2012) Gene expression and activity of phenyl alanine amonialyase and essential oil composition of Ocimum basilicum L. at different growth stages. Iran J Biotechnol 10:32-39

doi:10.1186/s40529-014-0041-y

Cite this article as: Cruz et al: Comparison of leaf anatomy and essential oils from Drimys brasiliensis Miers in a montane cloud forest in

Itamonte, MG, Brazil. Botanical Studies 2014 55:41.

\section{Submit your manuscript to a SpringerOpen ${ }^{\circ}$ journal and benefit from:}

- Convenient online submission

- Rigorous peer review

- Immediate publication on acceptance

- Open access: articles freely available online

- High visibility within the field

- Retaining the copyright to your article

Submit your next manuscript at $\gg$ springeropen.com 